\title{
«GENTE DE MAL VIVIR»: FAMILIES AND INCORRIGIBLE SONS IN NEW SPAIN, 1721-1729
}

\author{
POR
}

\section{BEATRIZ CÁCERES MENÉNDEZ \& ROBERT W. PATCH}

University of California, Riverside

En la Nueva España el traslado forzoso de individuos a las Islas Filipinas y Marianas fue una forma de exilio equivalente a la deportación para castigar a los criminales y a la gente considerada indeseable. Los condenados fueron siempre hombres y usualmente españoles nacidos en América. Tanto el gobierno virreinal como los padres de familia pensaron en el traslado forzoso como un medio apropiado para limpiar el Reino no sólo de criminales sino también de "gente de mal vivir», es decir, aquellos dedicados al juego, la embriaguez pública, la ociosidad y la inmoralidad. Padres, hermanos y aún esposas utilizaron el traslado obligado como un medio para eliminar a los familiares cuyos comportamientos amenazaban manchar el honor de la familia.

PALABRAS ClAVES: Familia, honor, género, criminalidad, inmoralidad, traslado forzoso.

Recent historiography of colonial Latin America has demonstrated the function of families as the agent of social control. Most importantly, scholars have shown how patriarchal power and the sense of family honor not only restricted the lives of women but also punished them for transgressions ${ }^{1}$. Yet, because of

1 The literature on family and honor in colonial Spanish America is lengthy and growing. See Josefina MURIEL, Los recogimientos de mujeres: Respuesta a una problemática social novohispana, México, Universidad Nacional Autónoma de México, Instituto de Investigaciones Históricas, 1974; Patricia SeEd, To Love, Honor, and Obey in Colonial Mexico: Conflicts over Marriage Choice, 1574-1821, Stanford, Stanford University Press,1988; Ann TwINAM, «Honor, Sexuality, and Illegitimacy in Colonial Spanish America», Asunción LAVRín (ed.), Sexuality and Marriage in Colonial Latin America, Lincoln, University of Nebraska Press, 1989, pp.118-155; Ramón A. GuTIÉRrez, When Jesus Came, the Corn Mothers Went Away: Marriage, Sexuality, and Power in New Mexico, 1500-1846, Stanford, Stanford University Press, 1991; M. I. VIFORCos MARINAS, «Los recogimientos, de centros integración social a cárceles privadas: Santa Marta de Quito», Anuario de Estudios Americanos, Vol. L, núm. 2, Sevilla, 1993, pp. 59-92; SIMPOSIO DE HISTORIA DE LAS MENTALIDADES, Comunidades domésticas en la sociedad novohispana: formas de unión y transmisión 
the scarcity of sources, little has been said about the punishment of male children for resistance to parental power and offenses against family honor. This essay will address this aspect of family and parental power by discussing the punishment of incorrigible male children. It will do so by analyzing a registry of people transported to the Philippines and the Mariana Islands (Guam) during the colonial period, for many of the people exiled across the Pacific were men guilty of conduct that dishonored their families.

The policy of transporting people from Mexico to the western Pacific islands began in 1626, when the king of Spain, having been informed of the shortage of soldiers in the Philippines following an attempted Dutch invasion, authorized the viceroy of New Spain to round up the «gente llovida» (presumably people in the colony without permission) and vagabonds and transport them to the islands across the Pacific ${ }^{2}$. It is not known when this policy began to be put into effect, but a royal order of 1700 instructed the viceroy to send all the convicts and vagabonds condemned to serve in presidios «que suelen dirigirse a Filipinas» to Española instead, thereby demonstrating that the government in fact had been transporting people across the Pacific ${ }^{3}$. The practice apparently took place during most of the colonial period in America. During the War for Mexican Independence the Spanish government was still condemning people to exile in the Marianas or the Philippines ${ }^{4}$.

cultural, México, Instituto Nacional de Antropología e Historia, 1994; Ana María Alonso, Thread of Blood: Colonialism, Revolution, and Gender on Mexico's Northern Frontier, Tucson, University of Arizona Press, 1995; Cheryl English MARTIN, Governance and Society in Colonial Mexico: Chihuahua in the Eighteenth Century, Stanford, Stanford University Press, 1996; Lyman L. JoHNSON and Sonia LIPSETT-RIVERA (eds.), The Faces of Honor: Sex, Shame, and Violence in Colonial Latin America, Albuquerque, The University of New Mexico Press, 1998; A. TwinAm, Public Lives, Private Secrets: Gender, Honor, Sexuality, and Illegitimacy in Colonial Spanish America, Stanford, Stanford University Press, 1999. For Spain, see Bartolomé BENASSAR, L'homme espagnol: Attitudes et mentalité du XVI au XIX siècle, Paris, Hachette, 1975. The original formulation of the honor-shame complex comes from anthropology: see J. A. PITT-Rivers, The People of the Sierra, London, Weidenfeld and Nicolson, 1954; J. G. Peristiany (ed.), Honour and Shame: The Values of Mediterranean Society, London, Weidenfeld and Nicolson, 1966; Julian PITT-RIVERS, «Honor», David L. Sills (ed.), International Encyclopedia of the Social Sciences, New York, Macmillan, 1968, vol. 6, pp. 503-510; Julian PitT-Rivers, The Fate of Shechem: or the Politics of Sex: Essays in the Anthropology of the Mediterranean, Cambridge, Cambridge University Press, 1977.

2 Richard KonetzKe (ed.), Colección de Documentos para la Historia de la Formación Social de Hispanoamérica, 1493-1810, vol. II, Madrid, Consejo Superior de Investigaciones Científicas, 1958, p. 290.

3 Richard Konetzke (ed.), Colección de Documentos para la Historia de la Formación Social de Hispanoamérica, 1493-1810, vol. III, Madrid, Consejo Superior de Investigaciones Científicas, 1962, pp. 83-84.

4 Eric Van Young, The Other Rebellion: Popular Violence, Ideology, and the Mexican Struggle for Independence, 1810-1821, Stanford, Stanford University Press, 2001, pp. 118, 197, 286. 
Although several thousand people were forcibly transported from New Spain to the Spanish islands in the western Pacific during Mexico's colonial period, virtually nothing is known about the practice or the people involved. Consequently, the registry of the 220 individuals transported against their will across the Pacific between 1722 and 1728 provides us with the only evidence thus far discovered about the policy and about the exiles (for in effect, transportation to the Philippines and the Marianas was social exile, the equivalent of deportation $)^{5}$. Three-quarters of these people had been convicted by the criminal courts of the Audiencia of México in Mexico City or the Audiencia of New Galicia in Guadalajara. The remainder were people judged to be undesirable; their cases were handled by the viceroy, who designated a magistrate to investigate the cases of people being considered for exile.

The registry of exiles is important not simply because it is the only known evidence of the policy of forced transportation. It is also significant because of the quality of information it includes about those being considered for exile. Family members, family friends, and neighbors testified in what amounted to deportation hearings and trials, thereby providing valuable information about perceptions of proper behavior and of deviance from social norms. The testimony provides us with small stories told by people from diverse backgrounds and sometimes expressed in their own words. In the absence in the Hispanic world of diaries - an important source of information regarding innermost thoughts in the English-speaking world - these expressions of emotional pain and suffering, made as people agonized over right and wrong, over proper behavior and deviance from that behavior, and over honor and shame, give us rare insight into the inner workings of Hispanic culture in America.

This essay will focus on family honor not only among the elite but also among the middle and lower social strata of Spanish society in Mexico. We shall demonstrate how families in effect eliminated adult children who were guilty of behavior that threatened to stain family honor. Since some scholars have suggested that Hispanic males were free from the restraints of morality, while females were not, our research will contribute to a better understanding of gender in colonial Spanish America ${ }^{6}$. We shall show how the conduct of male children was of

5 The registry was sent to the governor of the Philippines, the Marqués de Torre Campo, who in turn submitted it during his residencia in 1730. See Residencia del Marqués de Torre Campo, 1730, Archivo General de Indias (Seville) (hereafter cited as AGI), Escribanía de Cámara 425B. Unless otherwise stated, all primary source citations are from this document.

${ }^{6}$ For examples of this interpretation, see GuTIÉRREz [1]; Lee M. PENYAK, «Safe Harbors and Compulsory Custody: Casas de Depósito in Mexico, 1750-1865», The Hispanic American Historical Review, vol. 79, núm. 1, Durham, 1999, pp. 83-99. The thesis of unrestrained male immorality has also been challenged for England. See Bernard CAPP, «The Double Standard Revisited: Plebeian Women and Male Sexual Reputation in Early Modern England», Past and Present, núm. 162, Oxford, 1999, pp. 70-100. 
the utmost importance for the preservation of family honor. For honor, as scholars of Latin America have for the most part agreed, was dependent completely on public perception, not on private or individual conceptions of self-worth ${ }^{7}$.

Transportation or exile in colonial Mexico served the purpose of purifying society by purging those who were considered incorrigible, dishonorable, or criminal. Exile, however, as a policy was first of all ethnically specific: Indians were almost totally excluded from sentences of forced transportation across the Pacific, for they were usually punished in other ways. As Table 1 demonstrates, with only two exceptions in the records (a counterfeiter and an Indian noble), all the exiles were either «españoles» (meaning Spaniards from Spain or Mexicanborn creoles) or mixed-race people (mestizos, mulattoes, castizos, and «coyotes»). In reality, however, only three of the españoles were from Spain. Spanish Mexicans, who were referred to as American Spaniards, were the preponderant element among those exiled to the Philippines or Marianas, for they made up almost exactly three-quarters of the total. Forced transportation, therefore, was not the means chosen by a Spanish-controlled power structure to get rid of people thought to be racially inferior, for modern racism had yet to develop fully. This form of punishment was also gender specific: it was applied to men but not to women. Nevertheless, it could have deleterious consequences for women and the family unit.

Forced transportation was an expensive expedient, and usually the crown had to pay the costs of shipping the people from Acapulco to Manila or the Marianas. This was because the policy did not serve - as it sometimes did in other historical circumstances - as a means of easing a labor shortage at the receiving end. Across the Pacific there were no private citizens willing to defray the costs of transportation in return for labor. The government, however, did find these exiles useful because it needed soldiers to garrison presidios in a part of the world where very few Spaniards were willing to live, let alone serve in the military. Therefore it sentenced people to military service in the Philippines and the Marianas. It also ordered a large number of people to serve across the Pacific as sappers (gastadores), that is, forced laborers who were required to work on military projects like the building and repair of forts and fortifications. In effect, exile was usually

7 GUTIÉRREZ [1] argues that honor was important as a value that asserted the superiority of Spaniards over Indians and of white heterosexual males over all females. Steve Stern, on the other hand, suggests that the importance of honor in colonial Spanish America has been exaggerated, for in gender relations and conflict the violation of rights and obligations was the guiding principle at work, and he doubts the very existence of an honor code among the non-elites of New Spain. See Steve J. Stern, The Secret History of Gender: Women, Men, and Power in Late Colonial Mexico, Chapel Hill, The University of North Carolina Press, 1995. 
carried out to further state interests by providing the army with soldiers and with cheap laborers for military projects. Moreover, criminals, depending on the nature of their crimes, were frequently required to serve without pay.

Of course, the crown did not exile all those convicted of crime. The great majority of criminals in colonial Mexico were fined or sentenced to flogging, imprisonment, hanging, or military service or convict labor in Mexico itself. Moreover, it is likely that Spaniards were not as preponderant among criminals in general as they were among the exiles in Table 1 . That was certainly the case in the late eighteenth century and in the first decade of the nineteenth, as Gabriel Haslip-Viera and Teresa Lozano Armendares have shown ${ }^{8}$. In other words, exile across the Pacific was special punishment.

TABLE 1: Racial/ethnic category of people transported from

New Spain to the Philippines/Marianas, 1722-28

\begin{tabular}{l|c|c} 
CATEGORY & NUMBER & PERCENTAGE \\
\hline Spaniards & \\
Mestizos & 141 & 74.2 \\
Castizos $^{2}$ & 31 & 16.3 \\
Mulattoes $_{\text {Coyotes }}{ }^{3}$ & 7 & 3.7 \\
Indians & 7 & 3.7 \\
& 2 & 1.1 \\
\cline { 2 - 3 } & 2 & 1.1 \\
\hline
\end{tabular}

Note: 190 of 220 deportees ( $86.4 \%$ ) were identified by racial/ethnic category.

Source: Residencia del Marqués de Torre Campo, 1730, AGI, Escribanía de Cámara 425B, fols. 119-246.

1 Both European-born and American-born Spaniards. Only three Spaniards were identified as being from Europe.

2 Offspring of a Spaniard and a mestizo.

3 A mixture either of all three races or of mestizo and Indian. Only two people were identified in this category.

Forced transportation was also punishment for special criminals. Table 2 summarizes the cases of the 183 exiles whose crimes or offenses were identified in the years between 1722 and 1728. Clearly, crimes against property were by far the most important offense. This is in contrast to what Haslip-Viera has demons-

8 Gabriel Haslip-Viera, Crime and Punishment in Late-colonial Mexico City, 1692-1810, Albuquerque, The University of New Mexico Press, 1999, pp. 58-59; Teresa LozANo ARMENDARES, La criminalidad en la ciudad de México, 1800-1810, México, Universidad Nacional Autónoma de México, Instituto de Investigaciones Históricas, 1987, pp. 117-151. 
trated for Mexico at approximately the time, for crimes against property made up only one quarter of the total ${ }^{9}$. This was because the crown turned to forced transportation across the Pacific as a means of punishing career criminals, whose crimes therefore were most likely to be against property, and hence the prominence in the records of pickpockets, picklocks (easily identifiable because they were caught with their special tool, the ganzúa), rustlers (ladrones cuatreros), and highway robbers (salteadores de caminos). The government also chose to inflict this extreme form of punishment on counterfeiters, for these people's crime was in fact lèse majesté. The state even sent some murderers overseas. There were also several people exiled for illicit sexual offenses, especially adultery (which was a criminal offense), and for wife-beating.

TABLE 2: Crimes/offenses of 183 people transported from New Spain to the Philippines/Marianas, 1722-28

\begin{tabular}{l|c|c} 
CRIMES/OFFENSES & NUMBER & PERCENTAGE \\
\hline Against property & 97 & 53.0 \\
«Undesirable» & 44 & 24.0 \\
Violent & 11 & 6.0 \\
Sexual $^{1}$ & 6 & 3.3 \\
Lèse majesté2 $^{\text {Multiple }}$ & 6 & 3.3 \\
Wife abuse & 6 & 3.3 \\
Military & 5 & 2.7 \\
Blackmail & 5 & 2.7 \\
Kidnaping & 2 & 1.1 \\
& 1 & 0.5 \\
\hline
\end{tabular}

Note: the crimes/offenses of 183 of 220 deportees $(83.2 \%)$ were identified. Source: same as Table 1.

${ }^{1}$ Includes adultery (3 cases), bigamy (1), sodomy (1), and attempted seduction of a married women (1).

25 cases of counterfeiting, 1 case of stoning the guards of the Royal Palace

3 excludes those whose crimes included murder; these people are listed under «violent».

4 desertion and dereliction of duty.

On the other hand, one-fourth of those exiled in fact had committed no crime. The government nevertheless judged them to be undesirable because of their immoral, although not necessarily illegal, behavior. Indeed, even when people

9 HASLIP-VIERA [8], p. 54. Specifically, this scholar shows that crimes against property made up 22.0 percent of total crimes in 1710 and 17.6 percent in 1741 . 
were found to be innocent of the crimes of which they were accused, royal officials had the power to declare them to be undesirable and ship them out. This happened to people known to associate with criminals, as well as to those judged to be indolent, habitually drunk, lazy, or vice-ridden. Guilt by association was a basic principle of justice, and it was used to get rid of people who were said to be associating with «gente de mal vivir» - people of evil living. Those whose behavior was perceived as a threat to a family's honor were put into this category of the undesirable. We shall say more about them below.

Significant differences in criminality existed between Spaniards and nonSpaniards who were forcibly transported across the Pacific. Table 3 demonstrates that non-Spanish exiles were much more likely than Spaniards to have committed crimes against property and to be over-represented among the counterfeiters. By the same token, Spaniards were more likely to be considered undesirable or to be transported for wife abuse, sexual offenses, blackmail, and kidnaping; indeed not one non-Spaniard was exiled for the latter crimes. In other words, while crimes of property were those most often punished by transportation, other offenses and crimes to which Spaniards were especially prone were also considered to be just cause for exile across the Pacific.

Since crimes against property are usually committed by those who have none, the policy of forced transportation naturally was implemented more against the poor than against the rich. Nevertheless, high-status Spaniards, identified with don before their names, were also forcibly transported. A total of 16 such men, or 7 percent of the total, were in this category of gentlemen ${ }^{10}$. The offenses of ten of this group were identified. Three committed crimes against property, which is not surprising for not all gentlemen had money. Nevertheless, these high-status Spaniards were more represented in the other categories of offenses. One of the two cases of blackmail was committed by a gentleman, don Pedro Cruces, a native of Galicia. Two of the five people exiled for wife abuse, don Pedro Fernández Vela and don José Infante Delgado, were high-status Spaniards. Three of the 44 people forcibly transported for being undesirable were in this category. And there is the interesting case of don Manuel de Canales, a gentleman given five years of exile

10 The use by the escribanos of the status-indicator don was never perfect in colonial records and therefore it is not 100 percent accurate in determining who was of higher status and who was not. Nevertheless, in early eighteenth-century Mexico there was still considerable social agreement on who qualified to be a don and who did not. Fortunately many people appear in the records more than once, thus allowing for a check of consistency of usage. Of the 33 individuals who appear more than once, 32 of them do so in exactly the same manner; that is, they are either called don on every occasion or they are never called don on any occasion. Most of the time two different escribanos on opposite sides of the Pacific made the separate notations, thus demonstrating considerable agreement on the criteria being used for classification. The almost perfect internal consistency demonstrates that the term had social meaning. Therefore it can be used as a rough, although not exact, guide to the status of an individual. 
in the Philippines for the crimes of adultery, illegal possession of weapons, and what were referred to as «otros excesos» ${ }^{11}$.

TABLE 3: Crimes/offenses by spaniards and non-spaniards among deportees to the Philippines/Marianas, 1722-28

\begin{tabular}{l|rr|rr}
\multirow{2}{*}{ CRIMES/OFFENSES } & \multicolumn{3}{|c|}{ SPANIARDS } & \multicolumn{2}{|c}{ NON-SPANIARDS } \\
& \multicolumn{2}{|c|}{$\mathrm{N}^{\circ}$. } & $\%$ & \multicolumn{2}{c}{$\mathrm{N}^{\mathrm{S}}$. } & \multicolumn{1}{c}{$\%$} \\
\hline Property & 62 & 51.7 & 28 & 71.8 \\
«Undesirable» & 31 & 25.8 & 4 & 10.3 \\
Violent & 8 & 6.7 & 1 & 2.6 \\
Sexual & 5 & 4.2 & - & - \\
Lèse majesté & 3 & 2.5 & 3 & 7.7 \\
Multiple & 2 & 1.7 & 3 & 7.7 \\
Wife abuse & 5 & 4.2 & - & - \\
Military & 1 & 0.8 & - & - \\
Blackmail & 2 & 1.7 & - & - \\
Kidnaping & 1 & 0.8 & - & - \\
& 120 & 100.1 & 39 & 100.1 \\
\hline
\end{tabular}

Source: Same as Table 1.

What makes this documentation especially valuable to the historian is the discussion accompanying many of the cases in the registry of men being considered for forced transportation. Rarely do the records of the Spanish Empire provide us with so much insight into both family conflict and the real fear and consternation felt by people of both common and elite backgrounds. A good example of the latter is don Baltazar Martínez de Guajardo, a native of Puebla. This Spaniard of high status (hence the don before his name) begged to remain in New Spain, pointing out that exile would lead to the destruction of his family. In his formal petition to the king he emphasized that he was «cargado de hijos y mujer», had already spent four years in jail in Acapulco, and had never been informed of the reason for his detention. The viceroy ordered an inquiry, which revealed at first that there was no record of the case. A second search was then made, but whatever was found must have been scandalous, because the viceroy chose to keep it a secret. Without further ado Martínez de Guajardo was sentenced to transportation to the Philippines for three years, with the warning that should he violate his exile his sentence would be doubled ${ }^{12}$.

\footnotetext{
11 Folio 128.

12 Folio 174.
} 
Exile, of course, stripped men of family support. Thus Toribio Fernández, who had committed the crime of perjury and had been condemned to three years of exile, expressed his distress over having to leave a wife behind. He begged for his sentence to be changed to banishment somewhere on the mainland because, as he said, if sent across the Pacific he could not compel his wife «a que baya conmigo a pasar aguas de mar». Exile closer to home would permit him to enjoy «algún alivio y consuelo» of a wife. Separation from spouses caused deep concern among those being considered for exile because the females left behind and by themselves would be exposed to all sorts of «peligro y riesgo». Among these, one presumes, was infidelity, which itself could become a cause for the exile of other men.

TABLE 4: Crime and racial/ethnic category among 39 non-spaniards

\begin{tabular}{|c|c|c|c|c|c|c|c|c|c|c|}
\hline \multirow{2}{*}{ CRIMES } & \multicolumn{2}{|c|}{ Mestizos } & \multicolumn{2}{|c|}{ CASTIZOS } & \multicolumn{2}{|c|}{ MulatTOES } & \multicolumn{2}{|c|}{ COYOTES } & \multicolumn{2}{|c|}{ INDIANS } \\
\hline & $\mathrm{N}^{\mathrm{o}}$. & $\%$ & $\mathrm{~N}^{\mathrm{o}}$ & $\%$ & $\mathrm{~N}^{\mathrm{o}}$ & $\%$ & & & & \\
\hline Property & 21 & 84.0 & 3 & 50.0 & 2 & 50.0 & 2 & 100 & & \\
\hline «Undesirable» & 2 & 8.0 & 1 & 16.7 & & - & & & & 50.0 \\
\hline Violent & 1 & 4.0 & & - & & - & & & & \\
\hline Lèse-Majesté & 1 & 16.7 & 1 & 25.0 & & - & & & 1 & 50.0 \\
\hline \multirow[t]{2}{*}{ Multiple } & 1 & 4.0 & 1 & 16.7 & 1 & 25.0 & & & & \\
\hline & 25 & 100 & 6 & 100.1 & 4 & 100 & 2 & 100 & 2 & 100 \\
\hline
\end{tabular}

Source: Same as Table 1.

The state, however, depending on the conditions of the crime, could show a certain degree of lenience or mercy in the application of punishment. Sometimes banishment overseas was changed to exile closer to home. Toribio Fernández, alleging illness and poverty as well as the desire to avoid separation from his wife, ended up as one of the lucky ones. Instead of transportation to the Philippines for three years his sentence was changed to service in the presidio on the disease-infested Isla del Carmen (on the Bay of Campeche) ${ }^{13}$. The state on the other hand at all times exercised the right to reverse sentences depending on its needs. José de Almesiga, for example, having been sentenced to exile in the Marianas, was actually sent to California «por ser necesario allí por razón de su oficio». Presumably he would be put to work as a locksmith, since his «skill» in question was that of a picklock (ladrón ganzuero). But the reverse also happened, for sometimes the king's need for soldiers changed. Tomás Francisco, Bernardo Félix, José de Guevara, and Tomás Leyte, originally sentenced to military service in Mexico City, found themselves crossing the sea bound for the Philippines ${ }^{14}$.

\footnotetext{
${ }^{13}$ Folio 124.

14 Folio 158.
} 
In some instances carrying out the policy of forced transportation was a lengthy process. Don Baltazar Martínez Guajardo, as we have seen, spent four years as a prisoner in the Castle of Acapulco while waiting for his case to be resolved. He complained that he had been detained all that time «sin que se me tomase declaración ni haverseme oydo en derecho». To make matters worse, imprisonment prior to banishment could destroy men physically and morally. Prisoners were not provided with food, and each had to fend for himself, as don Baltazar pointed out when he complained that «por los hambres y trabajos que estoy pasando en dicha prisión é intentado cosas contra la fe». Detention in Acapulco was particularly detrimental to human well-being, for it meant exposure to physical danger, «pues a los mas robustos los deshallese este Puerto... por el mal temperamento de dicho Puerto» ${ }^{15}$.

Forced transportation could be either the cause or the result of marital infidelity. Adultery was a crime that could send a man on a journey of isolation from his own society. In these cases two men were involved: the lover who was the aggressor- adulterer, and the husband whose honor was assaulted. In this game of passion, the husband had all the rights on his side, and sometimes he went to extremes to avoid any potential female indiscretion. Transportation was a weapon that a husband could use to eliminate other males who might threaten his honor. It was not even necessary for infidelity to take place; just the hint of the possibility could be enough for a husband to take measures to prevent a conceivable public humiliation. Hence Juan de Estrada was condemned to serve as a soldier in the Philippines for a period of five years «por hacer ynquieta a cierta mujer casada» ${ }^{16}$. Marital infidelity with a relative could be another cause that forced men overseas. So Francisco de España was sent to the Marianas «por hazer mal tratamiento a su mujer, y comunicar torpemente a una prima suya» ${ }^{17}$.

Blackmailers tried to take advantage of society's attitudes towards infidelity. They sometimes believed that they could behave with impunity, assuming that women, fearing disrepute, would not come forward to denounced them. Nevertheless some women were bold enough to do just that and denounced blackmailers to the authorities. Thus don José San Gil Ylajustida, profiting from his special status as a European Spaniard (an advantage that opened doors for him to women of high social status), stole a trunk with two hundred pesos from the house of someone identified only as a «cierta dama». As result of his theft he was sentenced to transportation to the Philippines for three years. The state as guardian of female honor did not reveal the lady's name ${ }^{18}$.

This interest in punishing adultery was motivated by the desire to protect the institution of marriage, which was understood to be vital for social stability. Yet

\footnotetext{
15 Folio 175.

16 Folio 229.

17 Folio 229.

18 Folios 218-219.
} 
the state's defense of that institution was not unconditional. When wife-beating was taken to extremes, the government used forced transportation to punish abusive husbands, and was willing to exile men for this offense regardless of social status. In the short run, of course, transportation across the Pacific also protected wives from further abuse. In the long run, some husbands may have returned and resumed their wife-battering, but the odds were good that many would not make it back from the Philippines or the Marianas ${ }^{19}$.

The royal government was especially likely to exile people who committed crimes of lèse majesté. Sometimes these could be of a petty nature. Sixteen-year old Benito Larraga was sentenced to two years in the Marianas for being an agitator (alborotador). His offense: throwing stones at the guards of the viceregal palace while they were transporting a prisoner ${ }^{20}$. Most crimes against the state were of a more important nature. The most serious, and most common, of these was counterfeiting, which was punished with forced transportation regardless of the social status of the perpetrator of the crime. Thus Spaniards Juan Velázquez and Miguel de Orifel, a coppersmith and a silversmith respectively, were banished for having used their metallurgical skills to make false coins. The mulatto Francisco Hilario and the castizo Juan Valentín were sent to the Philippines for the same crime. Counterfeiting was considered so egregious that even Indians engaged in this activity were not spared from the punishment of transportation. This seems to have been the only crime for which the state condemned the indigenous people to trans-Pacific exile. Thus Salvador Manuel, a twenty-five year old Indian found guilty of counterfeiting, was sentenced to the Marianas for a period of four years ${ }^{21}$.

Forced transportation was applied to criminals who were repeat offenders. Thus mulattoes like Mateo Panchano, who had not even served his first sentence when he was again involved in problems with justice, was sent overseas for a period of four years for his second offense. ${ }^{22}$ Others such as Juan Miguel, originally sentenced to forced labor in an obraje, ran away and was just beginning to enjoy the pleasures of freedom when he was detained for another offense and shipped across the Pacific ${ }^{23}$. The same thing happened to the castizo Juan José Neria, a candy maker, who went to Mexico City to avoid justice in Atrisco (Puebla) only to be suspected of burglary. He was sentenced to transportation to the Philippines ${ }^{24}$.

In the case of exiled Spaniards and mestizos, the crime most commonly committed was robbery carried out by professional burglars ${ }^{25}$. The candy-maker

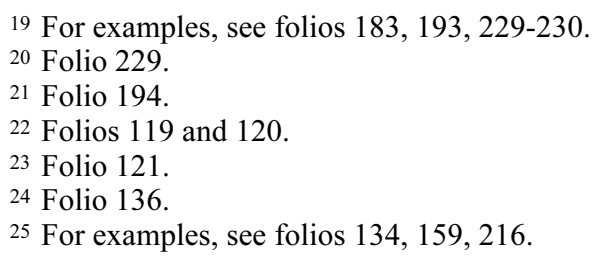


Juan José Neria, for example, already a fugitive from justice, was caught out at night carrying a crowbar (rejón). That by itself was considered grounds for forced transportation. Blackmail and fraud were also commonly practiced, and were justification for sending across the Pacific even Spaniards of high status. Thus don Juan Antonio de Bustamante, «sin embargo de Apelación y de la calidad», was exiled for six years for defrauding people with false bills of exchange. Also transported was don Pedro Cruces, a native of Galicia, who had attempted to extort money from the Marquesa of Altamira ${ }^{26}$.

The Church also embraced forced transportation as a means of disciplining its own priests. The Mercederian Friar Miguel Gutiérrez, for example, was declared to have committed grave violations of the constitution of his order and was found to be guilty of «incorregibilidad», although the Church was not required to state just what his crimes had been. After being expelled from the Order, he was banished to the Philippines. He nevertheless retained his ecclesiastical immunity, although because he was no longer a friar he was only allowed to wear the habit of a secular priest ${ }^{27}$.

The ecclesiastical courts could also order the transportation of non-priests for they had jurisdiction over laymen arrested on church property. Pedro del Castillo, for example, was a thief who tried to hide in a cemetery ${ }^{28}$. No less than 42 of the 220 people who were transported, or 19 percent, were arrested under these circumstances, which suggests that a lot of people thought that the Church would provide them with sanctuary. It did not, for bishops and archbishops agreed with the civil authorities on the benefits of the policy of transportation, especially since the jails of New Spain - including those of the Church - were said to be overflowing with criminals. On the other hand, the Church did insist on its rights, and therefore even as it handed criminals over to the government it did so only so long as the crown recognized that the Church was not required to do so and also promised to respect the exiles' ecclesiastical immunity even when they were on the other side of the Pacific. This meant that they could only be sentenced to be gastadores, not soldiers ${ }^{29}$.

The ecclesiastical courts also had jurisdiction over anyone who committed an egregious crime against the Church. Thus Juan Manuel Vázquez, a «ladrón sacrilego», was transported to the Marianas to serve as a soldier for four years without pay $^{30}$. Needless to say, with both civil and ecclesiastical courts at work, there were frequent clashes over jurisdiction. When the carpenter Diego Ruiz, said to be an old man, killed the Franciscan friar Francisco Rodríguez del Castillo, the pastor of a parish near Tepeaca (Puebla), the civil court sentenced him to perpe-

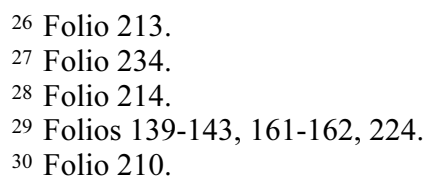


tual exile and service without pay in a hospital in Manila, but the Church demanded possession of the murderer in order to carry out special punishment prior to transportation. When Captain don Juan de Esparza, the alcalde of Mexico City, refused to hand him over, the Church threatened the city magistrate with excommunication. Esparza finally gave in, and Ruiz was tied by the hands to the door of the Cathedral of Puebla with a rope around his neck for one hour. Only then was the murderer allowed to be transported to what was undoubtedly his final residence ${ }^{31}$.

Although the documents provide the ages of the exiles in only slightly less than half of the cases, the eighty-four examples given are still useful. The average age of a man transported across the Pacific was twenty-six, which was appropriate for those sentenced to military service. Transportation was applied to people as young as fifteen years of age, like Manuel Suárez, a Spaniard who frequented the company of «delinquentes» and perpetrated a robbery ${ }^{32}$. The oldest of the exiles was don Fernando del Canto, a Spaniard who refused to state his age, but was judged to be over fifty «por su aspecto» ${ }^{33}$.

It is possible to observe a code of honor in Mexican Spanish society in the variety of aliases that flourished among the exiles. These were people without honor in society's eyes, and their condition as «moral outcasts» is easily appreciated in nicknames like «basura», «el venado», «el tigre», «palomo», «el cordero», «el zarco», «periquito», «tetas», «pestaña», «aguacero», «el fiestero», «el confuso», and so on. Honor was one of the most important values of Spanish colonial society and it is therefore no surprise to find that it was used by families concerned with their honor to accomplish the same goal as that pursued by the state: the elimination of undesirables.

\section{III}

There were many reasons why families, especially parents, would want to get rid of undesirable children. One of the most common was refusal to have gainful employment or a vocation in life. For Hispanic parents of all social classes in colonial Mexico, children with proper professions added to or maintained family honor. Therefore, educating the males of the family for a life-long career was of the utmost importance. Parents would have agreed with the Puritan adage that an idle mind is the devil's workshop, and even families of means were concerned that their children be employed in one way or another to keep out of trouble. The social position of a family was of course a crucial factor in the selection of a son's occupation. Nevertheless the social and economic structure of the time offered a limited range of opportunities from which to choose. For the most part, non-elite

\footnotetext{
31 Folios 166-172.

32 Folio 136

${ }_{33}$ Folios 228 and 142.
} 
people had to select an artisan trade or apprenticeship in a commercial house, while members of the elite attended schools of higher education to study for careers in the church, the law, or the bureaucracy ${ }^{34}$.

Despite the large number - some would even say surplus - of priests in New Spain, parents of means frequently sent their boys to the seminary in order to qualify them for positions in the Church. Whatever the religious motivations behind this may have been, the practice allowed parents to guarantee their sons' future income by endowing chantries (capellanias) for them. It was the promise of succession to a capellanía that encouraged youths to proceed with the long and costly studies necessary to become priests, and of course ecclesiastical careers, in Spain and in New Spain, were one of the most socially prestigious ways of earning one's living 35 .

Nevertheless, not all the young accepted what the old had in store for them. Some male children resisted efforts to direct their lives. Families with the means to endow chantries were therefore sometimes astonished, perplexed, and exasperated to find that a son refused to study for the priesthood even though upon graduation from the seminary he could count on living the easy life of a cleric with a guaranteed income. Don Miguel Pérez de la Barrera, a wealthy member of the elite from the Puebla region, succeeded in getting his two oldest sons to begin careers that eventually helped get them selected to serve on the town council of Atrisco, but his third son, don Gregorio, did not choose to pursue studies in the seminary. Instead, he ran away. The frustrated father complained to the viceroy regarding his son, who was not «atendiendo a lo ilustre de sus obligaciones y despreciando la inmediata susesión que tiene a muchas capellanías». Don Miguel requested that eighteen-year old don Gregorio be transported to the Marianas ${ }^{36}$.

When possible, families invested large amounts of money in male children's education. After spending such sums, parents felt that at a minimum their boys would learn to read and write, as the disgruntled don Pedro de Andraca complained regarding his son's shortcomings ${ }^{37}$. Parents' obligations, of course, were not limited to the provision of educational opportunities. As don Miguel Pérez de la Barrera's legal council described his client's activities as father, «en cumplimiento de la obligación... como padre de familia a tenido siempre procuró criar educando con sumo trabajo y exsaltas diligencias en buenas costumbres a don Gregorio Barrera su hijo» ${ }^{38}$. Uncles and brothers also contributed to raising the new generation. They could become surrogate parents, as in the case of don Carlos

34 Pilar Gonzalbo AizPuru, Las Mujeres en la Nueva España: Educación y vida cotidiana, México, El Colegio de México, 1987, p. 208.

35 Ida Altman, Emigrants and Society: Extremadura and America in the Sixteenth Century, Berkeley and Los Angeles, The University of California Press, 1989, p. 82.

36 Folio 203.

37 Folio 238.

38 Folio 203. 
Martel de Porres, who called a local merchant as a witness in the proceedings regarding his nephew, don Alonso de Esquivel. The witness, don Bernabé Venegas, testified that the uncle had given the nephew good upbringing, «teniéndole... en su Casa y compañía, y dándole con su maduro acuerdo el tratamiento y consejo que un Padre [da] a un Hijo a fin de inclinarlo a lo mejor» ${ }^{39}$.

Parents in return thought that their offspring had duties to perform for the rest of the family. Don Miguel Pérez de la Barrera, it will be recalled, spoke of «lo ilustre de sus obligaciones», which his son Gregorio was ignoring ${ }^{40}$. Parents also demanded obedience and respect from their children, complained when these were not forthcoming, and found ways to correct, discipline, or punish. They sometimes used benign methods. One father said that his efforts to change his son's behavior consisted of «educación y buena crianza» while another spoke of his «buenos tratamientos» ${ }^{41}$. When these methods proved unsuccessful, parents turned to more severe remedies. In some cases male children were sent to jail for a few months ${ }^{42}$. When that failed to effect a change in attitude and parents felt that their authority was being threatened, the last recourse was to banish the rebellious offspring. Despairing parents thus resorted to transportation in order to rid themselves of children for whom there was no hope.

The transportation registry offers insight into the aspirations that parents had for their children, and shows how they chose to get rid of their sons after their patience had been exhausted. An interesting life to start with is that of doña Úrsula de Nájera, an Indian cacica (noblewomen of the indigenous ruling class) from Mexico City. The formalities with which she introduced herself provide insight into the cultural identity and process of acculturation going on among people of her class. She identified herself as an Indian, but also pointed out her status of principala (member of the indigenous nobility). She switched from the terminology of one culture to the other, using, as she was allowed, the honorific title of doña, which was attached only to the names of privileged Spanish families and indigenous nobles. Doña Úrsula, in short, far from feeling inferior to Spaniards in status, brandished her equality with the best and superiority to the rest.

This cacica was a widow, and like many women of the time, she was involved in business activities. She owned a market stall and employed a friend to run it. She was the head of a household that included several servants. Nevertheless, although freer than a married woman (who was under the control of a husband), doña Ursula was by no means the social or legal equal of a man. Unlike a widower, in official records she had to emphasize that although without a spouse she was an «honest» female. Furthermore, because her family was not headed by a

\footnotetext{
39 Folio 154.

40 Folio 203.

41 Folios 238, 203.

42 For examples of this practice see folios 154, 160, 203.
} 
male, her capacity, although not her right, to raise children was suspect in society's eyes. Widows were considered to be weak and incapable of enforcing the discipline believed to be necessary for a proper education ${ }^{43}$.

Doña Úrsula, however, rather than fighting the prejudice against women, used it to her advantage. Knowledgeable in the ways of the world and of the Indian nobility's place in it, she tried to get her son to pursue an ecclesiastical career. In colonial times the priesthood was one of the few roads open to the native upper class in its struggle to preserve its threatened social status ${ }^{44}$. But all her plans came to naught, for her twenty-two year old son, don Juan Hipólito de León, had different ideas. He showed no interest at all in acquiring what his mother called a «good education». He did not apply himself to the exercise of any occupation, and worst of all - given the career choice made for him by others - he was entangled in an amorous relationship. His mother, needless to say, did not approve. Don Juan Hipólito even stole from his mother, and a witness testified that the son had insulted his mother and had shown disrespect. For two years doña Úrsula dealt with the problem without success, and when she felt there was no alternative, she claimed that as a woman she could not be expected to discipline her male child the way that a man could. She therefore had him transported across the Pacific ${ }^{45}$. (Don Juan Hipólito was one of the two Indians who made the journey)

Women were accused of failure as educators because of their gender. Men, on the other hand, were thought to be born with the capacity to train and control their offspring. Nevertheless, the transportation hearings disclosed a reality in which sometimes both male and female parents proved incapable of dealing with rebellious children. One father, don Miguel Pérez de la Barrera, blamed his failure as a parent on his advanced age and illness ${ }^{46}$. The stories of other fathers demonstrate that men as well as women failed to discipline their sons despite their best efforts.

One of the most common causes of conflicts between fathers and sons was habitual drunkenness. It also was of considerable importance to the state, for the colonial government grew increasingly concerned about growing lawlessness in the colonial capital and the role that alcohol supposedly played in causing popular unrest. Government officials believed that drunkenness had been a significant factor causing the Mexico City riots of 1692, when mobs had assaulted the viceregal palace and forced the viceroy to flee to the refuge of a convent ${ }^{47}$.

\footnotetext{
43 GonZalbo AizPuru [34], p. 210.

${ }^{44}$ Serge Gruzinski, «Familias, santos y capellanías: bienes espirituales y estrategias familiares en la sociedad indígena, siglos XVII y XVIII», SEMINARIO DE HISTORIA DE LAS MENTALIDADES, Familia y poder en Nueva España. Memoria del Tercer Simposio de Historia de las Mentalidades, México, Instituto Nacional de Antropología e Historia, 1991, p. 178.

45 Folio 149.

46 Folio 203.

47 Rosa FeIJoo, «El tumulto de 1692», Historia Mexicana, vol. XIV, núm. 4, México, 1965, pp. 656-679.
} 
As early as 1631 the government had tried to combat increasing drunkenness by prohibiting the manufacture of rum (aguardiente de caña) in the colony. The law, however, was widely ignored. On the other hand, the crown found that alcohol consumption could yield revenue and thus in 1668 had introduced the government-run pulque monopoly (asiento de pulques). This was abolished in 1692 as a result of the riots, only to be reinstated in 1697 after it was decided that pulque was not as dangerous as other alcoholic beverages and in any case produced needed revenues ${ }^{48}$. In the early eighteenth century the government again turned to the problem of drunkenness, not only because it was a danger to internal security but also because the illegal production of rum in Mexico competed with the brandy industry (aguardiente de uva) in Spain. The result was a proclamation in 1724 once more prohibiting local production of rum. It is doubtful that this law was enforced any better than the previous one, although at least one of the people transported to the Philippines in 1724, Diego José Cañadas, was exiled as punishment for manufacturing aguardiente ${ }^{49}$. The Juzgado de Bebidas Prohibidas, established in 1749 by order of the first Viceroy Revillagigeda, also failed suppress rum production and consumption, as did the measures implemented by José de Gálvez in the $1760 \mathrm{~s}^{50}$. The problem of drunkenness in Mexico City continued to get worse, as is demonstrated by the failure of the tavern and cantina regulations introduced in the 1790 s by the second Viceroy Revillagigeda ${ }^{51}$. Nevertheless, throughout the entire century the government was willing to use public drunkenness to justify forced transportation to the Philippines, and parents were willing to use it as proof of the moral failings of their children.

A more important cause of conflict between men and their families, however, was gambling. Games of chance, widely regarded as a vice (which is why the Real Hacienda monopolized the sale of playing cards) were a passion in Mexico during the entire colonial period. Conquistadors had been notorious gamblers, and sometimes lost their entire fortunes, including their encomiendas, in card or dice games. Indians and Africans, in turn, mixed their own games of chance with those of the Europeans to create a culturally and racially diverse underworld in which luck favored the few and separated the many from their property. Governments passed laws and issued proclamations prohibiting gambling, but the very repetition of these orders was a manifestation of their failure. The wealthy sometimes managed to conduct themselves with decorum by gambling in their own homes, but many people of all classes met in the streets to indulge their

48 José Jesús Hernández Palomo, La Renta del pulque en Nueva España 1663-1810, Sevilla, Escuela de Estudios Hispano-Americanos, 1979, pp. 31-84.

49 Folio 192.

50 José Jesús Hernández Palomo, El aguardiente de caña en México (1724-1810), Sevilla, Escuela de Estudios Hispano-Americanos, 1974, pp. 44-101.

51 Michael. C. SCARDAVILLE, «Alcohol Abuse and Tavern Reform in Late Colonial Mexico City», The Hispanic American Historical Review, vol. 60, núm. 4, Durham, 1980, pp. 643-671. 
weakness and bet on cock fights, bull fights, dice, card games and ball games, while the confidence man and the professional gambler - the notorious tahur made their living at the expense of others. Near the end of the colonial period the viceregal government, realizing that it could not suppress the vice, decided to profit from it and in 1770 founded the Mexican lottery. That was more realistic than to hope for moral improvement ${ }^{52}$.

Gambling could affect members of all social classes ${ }^{53}$. It caused intense distress and conflict within a family, and could ruin an entire household. No one knew this better than don Ildefonso de Astudillo, a master candle maker who planned to pass his occupation on to his son Pedro Cayetano. The continuity of careers from father to son seems to have been as important in New Spain as it was in Spain in the seventeenth century, for it minimized investment in tools and equipment or property and avoided the necessity of arranging a formal apprenticeship $^{54}$. But while don Ildefonso held high hopes for his son's future, Pedro Cayetano had only one passion in life, and that did not involve making candles. Gambling absorbed his days and nights. Thinking that he could change his son's behavior, don Ildefonso first had him sentenced to military service in Pensacola (Florida), where he served as a soldier of His Majesty for eleven years. But upon return to Mexico Pedro Cayetano immediately resumed, in his father's own words, his «depravadas costumbres de Bagamundo y Jugador» ${ }^{55}$. Don Ildefonso, having exhausted all the means available to correct his son's behavior and «temiéndose de su osadía mayor, e yrreparable el daño de su perdición», as a last resort requested that his son be transported to a presidio in either the Marianas or the Philippines.

This case is an example of how in New Spain both exile and military service were used to correct what was thought to be «deviant» behavior. The common chastisement was service as a soldier in a garrison located miles away from home. However, as a remedy for gambling, this measure probably had no success and may even have been counterproductive. Frontier posts and vices were a perfect marriage, for men with time on their hands frequently participated in games of chance and usually learned new vices as well. So the cure proved worse than the disease.

Gambling required an inexhaustible supply of money. Those addicted to this vice would do anything to get their hands on cash. After exhausting their own money they usually resorted to selling their property and even their clothes right

52 The best overall discussion of gambling in Mexican history is Ilán SEMO (coord.), La Rueda del azar: Juegos y jugadores en la historia de México, México, Pronósticos para la Asistencia Pública, 2000. See especially the chapter by Perla CHINCHILla PAWLING, «Lo lúdico y lo profano», pp. 55-91.

53 Lozano ARMENDARes [8], p. 146.

54 Altman [35], p. 106.

55 Folio 240. 
off their backs. Many eventually stole from parents and relatives. That was when children became a threat rather than an asset.

The family problems of don Carlos Martel de Porres illustrate the pattern. As was typical of Peninsular immigrants, don Carlos, unmarried and childless, had his nephew sent to him from Spain because he needed someone trustworthy and reliable to be his business associate. Unfortunately, he did not choose wisely, for the nephew, don Alonso de Esquivel Martel, lacked the qualities needed to preserve and maintain a family's fortune. Instead, he possessed defects. Most notably, he was a gambler and therefore was always in need of money. The closest at hand was that of his uncle, so he stole all that he could. He even ended up "vendiendo su ropa de vestir, y en que dormía», in the words of merchants who testified in the case ${ }^{56}$. Don Carlos had don Alonso incarcerated and held in chains for two months, but even that failed to improve the nephew. Eventually, to avoid further losses, don Carlos got rid of his less-than-useful relative by sending him on the long voyage to the Philippines (which was less expensive than sending him back to Spain). He even took exceptional security measures to make sure that don Alonso did not escape before the Manila ship left Acapulco ${ }^{57}$.

Parents of the lower social strata took the same measures as those of the elite to deal with their children's behavior. They sent their offspring to presidios or expelled them to the Philippines for the same «vices» attributed to children of the upper social strata. Thus Francisco de Leyte, who openly admitted his lowly condition, called three witnesses to testify in his behalf and asked the viceroy that his eighteen-year old son Tomás be sent to any of the overseas presidios. He made the request because of his son's «mal natural e inclinación a los vicios de Juego, y compañías osiosas y vagas de cuyas compañías, la ninguna aplicación e intrépido de su natural no se podía esperar sino que cayese en alguna fragilidad ${ }^{58}$. José Zerón, a Spanish resident of Mexico City, made the same complaint about his twenty-six year old son, and asked for his son's transportation because the latter was «ocioso y vagamundo y mal inclinado sin tener oficio y sin querrer ocupar en cosa alguna» ${ }^{59}$.

Parents had an explanation for the undesirable conduct of their children. They believed that human beings were born with a specific nature and were predetermined to be either good or bad. Parents sometimes said that their sons were «naturally evil» or had a «twisted nature». Some, of course, entertained hopes that the discipline of education, complimented by parental guidance, would save their children from themselves. But such measures often failed, as in the case of José

${ }^{56}$ Folios $155-156$. Since the witnesses in this and in several other cases testified using the exact same words, it is clear that lawyers frequently prepared their witnesses in advance of their appearance before the viceregal magistrate.

57 Folios 154-157.

58 Folios 145-148.

59 Folio 157. 
Joaquín Valentín, the adopted son of the Marquesa of Altamira, who lamented that she had tried to provide the boy with a «buena educación la que no a tenido efecto por su pernicioso natural» ${ }^{60}$. Bad results were also admitted by Captain don Miguel Velázquez Lorea, Magistrate of the Santa Hermandad and of the Real Tribunal de la Acordada (the special court set up to deal with rural crime). Velázquez Lorea had been entrusted with the education of Juan de Segura, whose parents eventually requested his expulsion from the colony. The magistrate noted that he found the case to be especially distasteful, for «haverle yo criado y no haver sido vastante mi educación para prevertirle [sic.] su pernicioso natural, y mala ynclinación». He therefore sentenced Segura and four other boys, at the request of their respective parents, to military service across the Pacific «por ociosos, vagos y mal entretenidos ${ }^{61}$. So, they would say, human nature prevailed in the end.

Parents were willing to banish their children for faults ranging from gambling to lack of respect to disobedience. But by far the main cause of transportation at the request of the parents was the sons' refusal to take up a trade in life. Idle people without a specific occupation were perceived to be a threat to their families. For people belonging to the provincial elite, like don Miguel Pérez de la Barrera, a son's indolence resulted in his mingling «con gente de baja esfera» ${ }^{62}$. But even persons like Dominga de Castro, who could not brag of any privileged background or condition, was dismayed over the tendency of her son, José Antonio Hilario Pérez, to be «metido continuamente en el Juego, sin haverse querido aplicar a ofizio ni travajo alguno, juntándose con gente de mal vivir» ${ }^{63}$.

The social reality of New Spain was characterized by the existence of what Julian Pitt-Rivers has called the «collective honour of groups». In real life this was expressed in the well-known Spanish proverb «díme con quién andas y te diré quién eres» («tell me who your friends are and I'll tell you who you are»). ${ }^{64}$ As Pitt-Rivers puts it, «the dishonourable conduct of one reflects upon the honour of all, while a member shares in the honour of his group. I am who I am subsumes whom I am associated with ${ }^{65}$. As a result, colonial Spanish society placed a high value on discretion. People were expected to learn how to preserve public appearances and avoid scandal. Most of the children who suffered banishment had led a publicly licentious existence that was punished with forced service in a presidio. Parents considered idleness, gambling, drunkenness and association with «gente de mal vivir» to be the road to perdition and the promise

60 Folio 243.

61 Folio 216.

62 Folio 203.

63 Folio 236. from his.

64 GUTIÉRREZ [1], p. 209, also cites this proverb. Our translation into English varies somewhat 65 PitT-Rivers, The Fate of Shechem [1], p. 13. 
of a lamentable and shameful end. When family members were shamed in the eyes of society because they could neither hide nor control the behavior of a child, they felt compelled to take steps to defend their honor.

Honor was the one thing that don Nicolás del Castillo de Altra, assistant parish priest and chaplain of the Augustinian Recoletas of Santa Mónica of the City of Puebla, could resort to when he asked for the removal of his brother don Ignacio. The clergymen lamented that «me hallo con un hermano bastantamente avieso y mal inclinado, y que por ningún camino he podido sugetar», and for these reasons he petitioned the viceroy to send his brother to a presidio in the Philippines. He took that step, the priest explained, to protect «la onrra y crédito de una familia de notorias, buenas y conocidas obligaciones de sangre» ${ }^{66}$. Honor, in short, for the elite was very much a matter of ancestry.

For the upper social strata, blood was believed to carry the honor of parents and grandparents ${ }^{67}$. Children were the recipients and guardians of that honor, especially if the reputation of the ancestor had brought them prestige through the holding of public offices. That is why don Miguel Pérez de la Barrera, in his request to banish his youngest son, called attention to the shame that the latter's behavior was bringing to the family's honorable reputation. That reputation had been established not just by his ancestors, who had held important public offices, but also by his two other sons, both of whom were or had been alcaldes of the town, one serving at that moment as regidor (city councilman) ${ }^{68}$. As Asunción Lavrín has shown, public men were expected to be role models for the nonelites $^{69}$. So, having a relative with a well-known «licentious» lifestyle was particularly damaging to the family's honor.

Family honor was a value deeply embedded in Spanish colonial society. Parents and other relatives were willing to sacrifice those members who refused to adjust their behavior to the code imposed by what was considered to be honorable conduct. This was done because of the meaning attached to the concept of honor in its relationship to the institution of the family. Pitt-Rivers' definition of family honor in twentieth-century Spain seems to suit the mentality of early eighteenth-century society in New Spain. Particularly striking is the «near paradox in the fact that while honour is a collective attribute shared by the nuclear family it is also personal and dependant upon the will of the individual conduct but produces consequences for others who share collective honour with this individual» ${ }^{70}$.

This paradox, that individual behavior could cause the entire family to fall into disrepute, was neatly expressed by don Francisco de Ascoytia when he recounted the character flaws of Antonio de Legarribas, who had been his son-in-law

66 Folio 177.

67 PITT-RIVERS, «Honor» [1], p. 505.

68 Folio 203.

69 Asunción LaVRíN, «Sexuality in Colonial Mexico: A Church Dilemma», in LaVRíN [1], p. 68.

70 PitT-Rivers, The Fate of Shechem, [1], p. 78. 
for sixteen years. He lamented that «aunque en todo este tiempo no a cumplido con lo que deve no me tiene tan conflictado lo referido... como el conciderarlo, como se sabe, y es público tan etregado y embevido en el Juego y embriagués» ${ }^{71}$. Ascoytia's daughter, doña Ana María, testified against her husband «por temer de los procederes de su marido la afrenta de sus hijos» ${ }^{72}$. Parents thus could dishonor their offspring by their conduct, just as children could bring dishonor to parents and other relatives through their bad behavior. As don Miguel Pérez de la Barrera explained it, he feared that the actions of his son, who was «de mala inclinación [y] entrepido de natural», would have an ignominious end and thereby dishonor him and his other children ${ }^{73}$.

Very importantly, Spaniards, whether high or low on the social ladder, had a sense of family honor that they were eager to protect against their children's licentious conduct. At the core of this was this social reality: the shame caused by their children's public behavior would be their own shame. This is clear in the case of Francisco de Leyte, the poor man who had requested that his son Tomás be sent to an overseas presidio for gambling and bad company. Leyte feared that his son's wicked nature would lead into committing an act that would be an affront to the family. Leyte clearly accepted the Spanish proverb that «mas vale precaver que tener que lamentar» (an English equivalent of which would be «a stitch in time saves nine»). In this case, however, the viceroy decided to sentence him to service not in the Philippines but in disease-ridden Acapulco ${ }^{74}$.

Preserving honor was so important that some people justified murder as a means of defending it. Thus Mathías de Figueroa, a soldier at the fort in Acapulco, killed his superior in a duel as well as a mestizo resident of the nearby town of Cacahuatepec. He carried out these acts in order to «defender su reputación» ${ }^{75}$. In Europe, of course, this was the justification for dueling. When honor was tarnished, it was necessary to restore it; otherwise disrepute could linger on and blemish the individual and the entire family. There were means by which debts of honor could be settled. Money could help to cover up scandalous behavior. But this method could be very expensive, and could even ruin a family. No one knew and wrote about this better than our oft-mentioned don Miguel Pérez de la Barrera, who blamed his impoverishment on his son and lamented that he lacked the wealth to put an end to the suffering caused by his son's conduct ${ }^{76}$.

It was in part for this reason that people turned to a cheaper method of preserving family honor. For transportation across the Pacific accomplished much. It prevented the delinquents from bringing further dishonor onto their families. A

\footnotetext{
71 Folio 144.

72 Folio 145.

73 Folio 203.

74 Folios 145-148.

75 Folio 200.

76 Folio 203.
} 
stitch in time really did save nine. This fear of the future was often stated as a reason for sending a son or relative across the Pacific. For example, José Zerón asked that his son («ocioso y vagamundo y mal inclinado») be expelled from the colony so that «no me denigre y afrente en lo de adelante [emphasis added] ${ }^{77}$. The same dread was felt by the cacica doña Úrsula de Nájera, who stated that her misbehaving son's expulsion to the Philippines would allow her to avoid «considerables daños y concequencias que de ellos veo, y maiores puedo esperer» ${ }^{78}$.

Don Francisco de Ascoytia's statement about his son-in-law, Antonio de Legarribas, makes clear the importance of having a good public image and the necessity of taking measures to preserve it. Legarribas had been married to Ascoytia's daughter Ana María for sixteen years and was the father of his grandchildren. Nevertheless don Francisco felt compelled to request his son-in-law's expulsion. He did not make the request, he said, because he had been forced to support his daughter's family out of his own pocket. Rather, he desired the transportation of Antonio de Legarribas to the Philippines because of the latter's behavior in public. Ascoytia complained that «es público» that his son-in-law was completely devoted to drinking and gambling, «con tanto extremo, que me temo, y por las compañías con que anda de que por mantener estos vicios, y no tener de donde adquerir dinero, no cometa otros mayores excesos y delictos que nos exponga a la nota de una afrenta». This was especially true «en tiempo que este Reyno se halla tan lleno de ladrones y facinerosos». Therefore, as a «precaución» - a stitch in time- Ascoytia and his daughter agreed to have Legarribas exiled to the Marianas or the Philippines, «para que alli [emphasis added] esté seguro de cometer ynfamia... que se teme» ${ }^{79}$. After determining that the father would support his daughter in her husband's absence, the viceroy sentenced Legarribas to a three-year exile in the Philippines.

This case makes clear that behavior was honorable only if it complied publicly with the code of conduct established by society. By the same token, transgressions lost their meaning when performed clandestinely. The norms and values of a culture only have meaning when individuals are participant members of it, and the code of conduct demanded by a particular social institution only has significance in its own context. By removing relatives from society family members no longer felt responsible for their behavior. What was not seen did not hurt them; ojos que no ven, corazón que no siente (out of sight, out of mind). And perhaps what was more important, families no longer had to worry about their honor.

Clearly, therefore, honor was not, as Julian Pitt-Rivers suggests, the secular equivalent of the state of grace without $\sin ^{80}$. For in a religious sense it mattered not

77 Folio 157.

78 Folio 150.

79 Folios 144-145.

80 See Julian PITT-RIVERS, «Postscript: The Place of Grace in Anthropology», in J. G. PERISTIANY and J. PITT-RIVERs (eds.), Honour and Grace in Anthropology, Cambridge, Cambridge University Press, 1992, pp. 215-246. 
at all if a sin were public or private, because it was known to God; it was a matter that concerned the individual and the omniscient Divinity. Honor and shame, on the other hand, were intrinsically social values. As long as a transgression could be hidden, it did not affect honor because society, unlike God, was not omniscient. For that reason, when discretion could not be maintained, expulsion - that is, transportation to a distant and different society — was the logical alternative.

Nevertheless, such a solution did have its costs. Those who requested the removal of their relatives were required to pay for transportation. Parents or other relatives, on the other hand, participated in determining the length of the sentence. Usually this was for a period of between one and five years. Nevertheless, some obviously angry relatives asked for longer sentences. The priest don Nicolás del Castillo de Altra, for example, considered his brother don Ignacio to be like a gangrenous member in need of amputation and thus requested that the exile be permanent. He asked that the governor of the Philippines put his brother «en un Presidio de donde no pueda salir en todos los días de su vida y adonde esté muy retirado, y lejos de embarcaciones que le puedan bolver a este Reyno» ${ }^{81}$. Other parents let the viceroy choose the length of the sentence. Don Ildefonso de Astudillo requested that his son be banished to any of the presidios of the Marianas or the Philippines «por el tiempo o perpetuidad que Vuestra Excelencia fuere servido» ${ }^{82}$.

Even when the viceroy approved transportation to presidios across the Pacific, there remained the fear that the exiles would find a way to escape and make their way back to New Spain. The possibility of the exiles' return was so dreaded by some people that they specifically requested the Marianas rather than the Philippines as the ultimate destination of those to be banished. This was because the Marianas were extremely isolated: the only ship that ever visited those islands was the very one carrying outcasts from New Spain to the Philippines. Escaping by stowing away was virtually impossible. Don Miguel Pérez de la Barrera therefore petitioned that his son serve His Majesty in the Mariana Islands because «se teme que buelva de las de Philipinası ${ }^{83}$.

The removal of children was possible because the law gave parents considerable power over their offspring. This was the principle known as Patria Potestas, which government officials did not dispute because the state recognized the value of the family as an institution of social control and stability. Parents of all social classes seem to have been well aware of their legal rights, and used them to defend their family honor. Thus don Miguel Pérez de la Barrera, of the elite, emphasized his privileges as a father when he sought to banish his son according to his rights under the Patria Potestas ${ }^{84}$. Similarly, when the lowly José Zerón re-

\footnotetext{
81 Folio 177.

82 Folio 241.

${ }^{83}$ Folio 204.

${ }^{84}$ Folio 204.
} 
quested the removal of his son, the judicial assessor of the viceroy stated that in this case «es lícito usar de la patria potestad para no experimentar alguna desonrra ${ }^{85}$. The state in fact vigorously supported this use of the family to maintain the values of society, for the king based his authority to rule over the people on the principle of parental rule over children. That, of course, was the essence of patriarchy.

Parents were able to exercise the prerogatives of parental jurisdiction, but only as long as their children were unmarried. Matrimony was a sacrament that could interfere with the Patria Potestas and allow the Church to check somewhat the power of parents. Ironically, this situation sometimes gave wives the upper hand over their in-laws or even over their husbands. That is why Gertrudís Manuela Castillo, a castiza married to Bartolomé González del Maso, whose parents were trying to have him transported to the Philippines, took steps to prevent her husband's exile. She made a written statement to the viceroy claiming that her father-in-law had presented her spouse for transportation «sin voluntad mía». She pointed out that the loss of her husband would mean great economic hardship, «por hallarme yo sin mas alivio que el suyo cargada de una hija, y con inumerables pobrezas y gongojas sin amparo alguno, y viendo que no he sido yo consentidora en dicha presentación» ${ }^{86}$. Thus, in order to resist one cultural principle, that of parental authority, Gertrudís Manuela Castillo resorted to another one, that of society's obligation to take care of women and children. The parents and relatives of Castillo's husband had testified that he and his friends were «mal inclinados», that he refused to find work, that he had already been put in jail before for involvement in fraud, and that he had been sentenced to serve an apprenticeship only to run away. Nevertheless, the viceroy acceded to the wife's request and canceled the transportation proceedings.

Banishment of a spouse for those women without the economic support of their kin could be a sentence to poverty and lead to the destruction of the nuclear family. Nevertheless a married couple's lack of monetary resources could prolong and strengthen the power of parents by delaying or preventing the establishment of an independent household. Hence economic dependence could counteract the freedom from Patria Potestas acquired by children through marriage. Women in this condition could be pressed to accept the decisions of parents or in-laws to transport their husbands. But this could also be a double-edged sword. At the same time that women could feel that they were being pressured into agreeing to the demands of their parents or in-laws, they in effect held the power to banish husbands whom they found undesirable.

These were the circumstances of the above-mentioned don Francisco de Ascoytia's daughter doña Ana María, who gave her consent for her spouse's remo-

85 Folio 157.

86 Folio 188. 
val. The husband, Antonio de Legarribas, as well as his wife and children, had been supported by his in-laws for sixteen years. Perhaps doña Ana María de Ascoytia was the one who wanted him exiled because of the continuous public humiliation that Legarribas' drunkenness and gambling inflicted upon her fami$1 y^{87}$. Her real motives will never be known. Conditions like this, nevertheless, would have allowed some women to exile their husbands, at least for a period of years, with the hope, perhaps, that the rigors and dangers of the trip across the Pacific would make their absence permanent. In this case the viceroy sentenced Legarribas to three years in the Philippines, but it also made it clear to doña Ana María de Ascoytia that afterwards she would have to resume marital life with him. In short, the state sometimes gave power to wives over husbands but would not countenance the weakening of the institutions of marriage and the family.

Sometimes parents were able to exile their married son or son-in-law, perhaps by reaching an agreement with the wife. However, it could also happen that an outcast could be brought back as a result of being married. This happened in the case of Francisco Romero, whose father had banished him «por haverse perdido el respecto a sus Padres». Having been transported to the Philippines with the sentence of five years as a soldier, Francisco was allowed to go back home after serving only three years because it was somehow discovered that he had a wife in Mexico. It was not explained why three years earlier the wife had been absent during the proceedings regarding her husband's transportation ${ }^{88}$. Thus matrimony granted women a certain degree of power against parents determined to maintain their dominion over their sons. But what marriage gave, lack of money took away. Without economic independence, parental authority could still control children.

When socially unacceptable behavior became public, it inflicted shame and dishonor not only on a particular family but on society as a whole. Individuals in New Spain keenly observed public deeds. Therefore the state, the Church, and the family sought to control public behavior in order to uphold the ideal conduct that was proclaimed and sanctioned by the social order. So the crown collaborated with parents in their effort to prevent or at least control actions that were judged to be dangerous to the harmonious functioning of the community. The main concern of the state was to restrict conduct that was potentially dangerous to the public at large. The viceroy's judicial assessor could thus argue that he considered it to be reasonable for parents to petition for the exile of their sons since «no se puede esperar buen efecto, sino un fatal paradero en perjuicio público» ${ }^{89}$.

The crown believed that it was advantageous to banish potential social transgressors with their transportation paid by the relatives. This saved the govern-

\footnotetext{
87 Folio 145.

88 Folio 193.

${ }^{89}$ Folio 157.
} 
ment the expense of paying those costs itself at a later time to rid society of criminals. For the crown, as for families, a stitch in time saved nine. The state in fact followed a policy of purging the community of those members who by their behavior rejected society's values. As Viceroy the Marqués of Casafuerte wrote about Antonio de Legarribas, the man being transported with the consent of his wife, «combiene limpiar esta Ciudad de hombres semejantes» ${ }^{90}$. The royal juridical assessor used the same sanitizing metaphor when he pointed out that the banishment of relatives at the insistence of the family was advisable because «combiene tanto limpieza la Ciudad de esta gente mal entretenida ${ }^{91}$. And indeed Mexico City in the early eighteenth century had serious problems of crime and vagrancy ${ }^{92}$. So, «atendiendo a la multitud de reos que se hallan en la Cárzel de este Juzgado» ${ }^{93}$, as one magistrate put it, transportation was like a magic wand that made troublesome people just seem to disappear.

\section{IV}

In eighteenth-century New Spain the honor of the individual was inseparable from that of the family and from the society that judged reputations. Individuals and groups struggled, using each and every family member, to maintain or enhance family honor. Parents therefore sought to control the behavior of male as well as female children in order to avoid disrepute and dishonor. Since family was based on a network of rights and obligations, parents felt it was their duty to take charge of their children's upbringing; in return they expected their sons and daughters to fulfill their obligations as members of the family. Heads of family could overlook transgressions as long as they did not threaten the honor of the group, because honor had precedence over rights and obligations. As a result, men were expected to conceal behavior regarded as unacceptable (e.g., drinking, gambling, loafing). When actions crossed the line between the private and the public, honor became an issue of more importance than the failure to carry out obligations. When their patience was exhausted and their reputation endangered, parents, brothers, and wives could and did remove their sons, brothers, and husbands. Hence honor was the value that checked dangerous conduct threatening the family as an institution.

The process of transportation shows that honor was not just a way of expressing an intangible value. It was also an effective tool of social control used by both families and the state. The crown acknowledged its significance, and gave the right to defend honor not only to the parents of elite status but even to those lower down the social scale. Nevertheless, while the conception of honor for the upper class was a question of birth, ancestry, and behavior, for the non-elite

\footnotetext{
90 Folio 145.

91 Folio 157.

92 Folio 144.

93 Folio 187.
} 
groups it was based exclusively on behavior. The elite may have created the code of honor, but the lower strata of society had adopted and adapted it. ${ }^{94}$ This was possible because of the inseparable connection between honor and public behavior ${ }^{95}$. Those who could not brag about their birth or ancestry could still feel that their conduct was honorable and that they were therefore eligible to claim a share of such an important value.

The state and the family thus acted in a similar way within their own spheres of operations, taking measures to control, discipline, and punish. When the family failed and individuals turned to crime, the state took care of them in the criminal courts. It was natural therefore that the state resorted to the simile of the family, and the power of the father over his children, to justify and explain its power; hence the patriarchal ethos of royal rule. Yet it was also in the interest of the crown to appear to be fair to all social classes. Consequently the vice-regal government transported across the Pacific people from all social strata.

Therefore the Spanish government in Mexico filled the ships bound for the Philippines and the Marianas with what the governmental and familial authorities defined as the dregs of society. People on the other side of the Pacific sometimes shared that opinion. In 1720 a priest in the Marianas lamented that «Los mas de los españoles que han venido en estos últimos años de la Nueva España son como la basura de ella», people who in some cases were exiles or vagabonds, and in others were youths running away from their parents. (Apparently some parental punishments were seen as even worse than exile and thus were worth escaping from). The priest went on to complain that the exiles were the cause of scandal in the islands, for they went about «enseñando a los naturales los vicios que antes no conocían y quitándoles el temor y la vergüenza para los que ya tenían conocidos». Since all the people exiled from New Spain were men, most were always in pursuit of women; as a result, «no dejan mujer ni doncella ni casada que no soliciten y engañen, apremiando aun con amenazas a los maridos, para que los dejen a su infame albedrío las propias mujeres y casas» ${ }^{96}$.

As far as is known, very few outcasts ever made it back to Mexico. The records include only three cases. One of these was Francisco Romero, the Spaniard transported in 1724 upon the request of his family because he had manifested lack of respect for his parents. He served as a soldier in Cavite (Manila Bay) from 1726 to 1729 but was then allowed to return to New Spain because it was discovered that he was married ${ }^{97}$. The case of another of the returnees, Pedro de Borda, suggests that sometimes people declared to be undesirable or even incorrigible were capable of reform. Borda was transported in 1723, having been sen-

\footnotetext{
94 MARTIN [1], especially pp. 144-148.

95 This is the principal thesis of the above-cited TwINAM [1].

${ }_{96}$ Cartas de los religiosos en las Islas Marianas, 1720, AGI, Filipinas 95.

97 Folio 184.
} 
tenced to four years of military service in the Philippines for idleness and drunkenness. On the other side of the Pacific, however, he apparently performed his duties conscientiously, for in 1725 he was promoted to sergeant and in 1727 rose to the rank of ensign (alférez). He returned to New Spain in $1728^{98}$.

The absence of information on the other outcasts strongly suggests that few, if any, ever succeeded in re-crossing the Pacific. For most, therefore, transportation was a one-way trip. Some of those sentenced to military service deserted and disappeared from the historical record. Many undoubtedly met the same fate as Manuel de Quiroz, a mestizo transported to the Philippines as an undesirable in 1724 . He served as a soldier in Manila from October 31, 1725 to March 1, 1727, when he died in the Royal Hospital in Manila ${ }^{99}$. Many of those who survived their sentences probably stayed, and given their previous inclinations undoubtedly were among the Spanish and Spanish-Mexican «vagabonds» mentioned in some colonial documents. For example, later in the eighteenth century the bishop of Nueva Cáceres (southeastern Luzon) reported that fully half of the non-native people of his diocese were men whom he described as «bagamundos perdidos», people who despite being European or Mexican Spaniards «se distinguen poco o nada de los naturales en su aspecto, traje, costumbres, idioma, y fortuna ${ }^{100}$. For better or worse, these outcasts of the islands with a tendency to «go native» were an important component of the people chosen, often against their will, to maintain Spanish culture in Asia.

Forced transportation to the Philippine and Mariana Islands, a form of social exile and the equivalent of deportation, was used in New Spain to punish criminals and people judged to be undesirable. Those who were sent across the Pacific were always male and usually American-born Spaniards. Both the viceregal government and parents thought forced transportation to be an appropriate way to rid Mexico not only of criminals but also of men "of evil living» - people whose lives were dedicated to gambling, public drunkenness, idleness, and immorality. Parents, brothers, and even wives therefore used forced transportation to eliminate unwanted family members whose behavior threatened to tarnish family honor.

KEY WORDS: Family, honor, gender, criminality, immorality, deportation.

Fecha de recepción: 26 de Diciembre de 2004.

Fecha de aceptación: 13 de Octubre de 2005.

98 Folio 130.

99 Folio 183.

100 Informe de Fray Antonio de Luca, Obispo de Nueva Cáceres sobre lon inconvenientes que se verifican para poner en practica los medios propuestos para la introduccion de la lengua castellana en las Yslas Filipinas, 1772, AGI, Filipinas 633, folio 5. 
